\title{
FAKTOR-FAKTOR AFEKTIF YANG MEMPENGARUHI PEMAHAMAN KONSEP MATEMATIKA SISWA SEKOLAH MENENGAH
}

\author{
Ulfa Lu'luilmaknun ${ }^{1}$, Nilza Humaira Salsabila ${ }^{2}$, Ratna Yulis Tyaningsih ${ }^{3}$ \\ 1,2,3 Pendidikan Matematika, Universitas Mataram \\ 1]ulfa_1@unram.ac.id
}

\begin{abstract}
This study aims to discuss several research results regarding the understanding of mathematical concepts that are influenced by affective factors possessed by high school students. Sources of data obtained from 9 research results consisting of 3 results of research on the effect of independent learning on students' understanding of mathematical concepts, and 3 results of research on the effect of self-confidence on students' understanding of mathematical concepts. From several research results, it can be concluded that motivation, learning independence, and self-confidence partially affect the understanding of high school students' mathematical concepts.
\end{abstract}

Keywords: Mathematic Concept Understanding, Motivation, Self-regulated Learning, Self-confidence

\begin{abstract}
Abstrak
Tujuan dari penelitian ini yaitu untuk membahas beberapa hasil penelitian mengenai pemahaman konsep matematika yang dipengaruhi oleh beberapa faktor afektif yang dimiliki oleh siswa sekolah menengah. Sumber data diperoleh dari 9 hasil penelitian yang terdiri dari 3 hasil penelitian mengenai pengaruh motivasi belajar terhadap pemaham konsep matematika siswa, 3 hasil penelitian mengenai pengaruh kemandirian belajar terhadap pemaham konsep matematika siswa, dan 3 hasil penelitian mengenai pengaruh kepercayaan diri terhadap pemaham konsep matematika siswa. Dari beberapa hasil penelitian, dapat disimpulkan bahwa motivasi belajar, kemandirian belajar, dan kepercayaan diri berpengaruh secara parsial terhadap pemahaman konsep matematika siswa sekolah menengah.
\end{abstract}

Kata kunci: Pemahaman Konsep Matematika, Motivasi Belajar, Kemandirian Belajar, Kepercayaan Diri

Cara Menulis Sitasi: Lu'luilmaknun, U., Salsabila, N.H., Tyaningsih, R.Y. (2021). Faktor-faktor Afektif yang Mempengaruhi Pemahaman Konsep Matematika Siswa pada Sekolah Menengah. Mathematic Education and Aplication Journal, volume 03 no. 2, halaman 17-24

Pembelajaran merupakan sebuah aktifitas yang kompleks. Dibutuhkan sinergitas dari berbagai macam komponen agar kegiatan pembelajaran tersebut dapat berjalan dengan baik. Selain itu, kegiatan pembelajaran yang terdiri dari serangkaian kegiatan belajar-mengajar yang melibatkan guru dan siswa membutuhkan komitmen yang tinggi dari kedua belah pihak. Dalam hal ini, komitmen dari murid tentu merupakan hal yang krusial. Ada banyak hal yang harus dilakukan oleh para siswa yang menujukkan tingkat komitmen mereka agar dapat terlibat aktif dalam sebuah proses pembelajaran. Salah satunya tentu bagaimana para siswa dapat memaksimalkan upaya mereka dalam memahami materi pembelajaran yang diberikan oleh guru di kelas. Oleh sebab itu, faktor pemahaman konsep menjadi bagian penting dalam indikator sebuah aktifitas pembelajaran dapat dikatakan berjalan dengan efektif atau tidak.

Pemahaman konsep merupakan hal yang penting dalam proses pembelajaran siswa di kelas. 
Dengan memiliki pemahaman konsep yang memadai terkait sebuah materi pembelejaran yang disampaikan, siswa akan lebih mudah dalam mencapai kemampuan dasar lainnya yang diperlukan dalam pembelajara matematika seperti penalaran, komunikasi, koneksi, dan pemecahan masalah. Dengan kata lain, pemahaman konsep merupakan hal fundamental bagi siswa yang dapat menjembatani mereka untuk dapat menggali lebih dalam terkait materi yang disampaikan oleh guru di kelas. Pemahaman konsep yang baik bagi siswa dapat membekali dirinya dalam memecahkan permasalahan matematika (Ferryansyah \& Azwar, 2020)

Konsep adalah serangkaian objek, simbol, atau kejadian yang memiliki karakteristik yang sama (Schunk, 2012). Pemahaman konsep adalah kemampuan menghubungkan antara konsep-konsep matematika, mempresentasikan matematika, serta mengenali contoh dan bukan contoh (Lu'luilmaknun \& Wutsqa, 2019). Indikator kemampuan pemahaman konsep menurut Riana, Kartinawati, dan Suhito (2019) adalah kemampuan untuk memahami ide-ide dalam pembelajaran matematika yang dapat diketahui dengan indikator sebagai berikut: (1) menyatakan ulang konsep yang dipelajari; (2) mengklasifikasikan objek sesuai sifat-sifat tertentu dengan konsepnya; dan (3) menyajikan konsep dalam berbagai bentuk representasi; (4) menerapkan konsep dalam pemecahan masalah.

Pemahaman konsep dalam pembelajaran matematika sangatlah penting dimana siswa dituntut untuk mampu menganalisis dan menyelesaikan persoalan matematis yang diberikan guru dalam soal terkait materi pembelajaran di kelas. Hal ini mejadi krusial dikarenakan banyak siswa yang telah mempelajari matematikan namun tidak memahami konsep dalam pembelajaran matematika yang sedang dipelajari tersebut. Hal ini dapat mengantarkan siswa pada ketidakpahaman terhadap materi yang disampaikan sehingga pada akhirya muncul persepsi yang umumnya berkembang bahwa matematika adalah mata pelajaran yang sulit. Pada tahap ini, pemberian pemahaman konsep yang kuat tentu merupakan hal yang wajib dilakukan oleh guru pada siswa saat pembelajaran matematika di kelas. Hal tersebut merupakan dasar yang dapat membekali siswa dalam lebih mengeksplorasi dan mamahami materi pembelajaran yang diberikan oleh guru.

Dalam proses pembelajaran di lapangan, ada beberapa faktor yang mempengaruhi pemahaman konsep siswa terhadap materi pembelajaran yang diberikan oleh guru. Beberapa faktor tersebut terbagi kedalam dua kelompok besar yaitu faktor afektif dan faktor kognitif. Faktor afektif terdiri motivasi belajar siswa (Risqilah, 2015), kemandirian belajar siswa (Winata, Friantini, \& Sukirno, 2021), dan kepercayaan diri siswa (Islami \& Rusliah, 2019). Sedangkan yang termasuk kedalam faktor kognitif antara lain kemampuan berpikir kritis (Belanisa, 2020) dan komunikasi matematis (Pradipta, 2018). Tujuan dari penelitian ini yaitu untuk membahas beberapa hasil penelitian mengenai pemahaman konsep matematika yang dipengaruhi oleh beberapa faktor afektif yang 
dimiliki oleh siswa sekolah menengah diantaranya yaitu motivasi belajar, kemandirian belajar, dan kepercayaan diri.

\section{METODE}

Penelitian ini merupakan studi literatur dengan menganalisis penelitian-penelitian terdahulu yang terkait. Faktor-faktor yang mempengaruhi pemahaman konsep belajar siswa terhadap materi pembelajaran matematika di kelas akan difokuskan pada faktor-faktor afektif seperti motivasi belajar siswa, kemandirian belajar siswa, dan tingkat kepercayaan diri siswa. Adapun sumber data berasal dari hasil penelitian-penelitian yaitu sebagai berikut: (1) Penelitian oleh Samsudin, Ningsih, dan Trisnawati (2021) yang berjudul "Pengaruh Model Pembelajaran dan Motivasi Belajar Terhadap Kemampuan Pemahaman Konsep Matematika (Eksperimen pada Siswa SMP Swasta di Kabupaten Lebak)." (2) Penelitian oleh Tona, Kesumawati, dan Marhamah (2019) yang berjudul "Kemampuan Pemahaman Konsep Matematis Berdasarkan Motivasi Belajar Siswa Melalui Model Pembelajaran LAPS-Heuristic." (3) Penelitian oleh Risqilah (2015) yang berjudul "Pengaruh Kemandirian Belajar dan Motivasi Belajar Melalui Model Examples Non Examples Terhadap Kemampuan Pemahaman Konsep Materi Kubus dan Balij di MTs Gondang Wonopringgo.” (4) Penelitian pertama oleh Winata, Friantini, dan Sukirno (2021) yang berjudul "E-Learning: Kemandirian Belajar terhadap Pemahaman Konsep Matematika pada Pembelajaran dengan Google Classroom.” (5) Penelitian oleh Setiawan dan Anawati (2021) yang berjudul "Pengaruh Konsep Diri dan Kemandirian Belajar terhadap Pemahaman Konsep Matematika.” (6) Penelitian oleh Yuliana, Surahmat, dan Fathani (2021) yang berjudul “Analisis Kemampuan Pemahaman Konsep Matematis Berdasarkan Kemandirian Belajar pada Materi Sistem Persamaan Linier Dua Variabel (SPLDV) Peserta Didik Kelas VIII MTs Ash-Sholihuddin Dampit.” (7) Penelitian oleh Islami dan Rusliah (2019) dalam penelitian mereka yang berjudul "Pengaruh Self-confidence Terhadap Pemahaman Konsep Matematis Siswa Sekolah Menengah Pertama." (8) Penelitian oleh Nurhandita, Marniati, dan Farman (2021) yang berjudul "Analisis Kepercayaan Diri Siswa dalam Pemahaman Konsep Matematis Siswa Sekolah Menengah Pertama.” Dan (9) Penelitian oleh Dini, Wijaya, dan Sugandi (2018) yang berjudul "Pengaruh Self-Confidence Terhadap Kemampuan Pemahaman Matemtika Siswa SMP."

\section{HASIL DAN PEMBAHASAN}

Seperti yang telah disampaikan pada awal tulisan ini, bahwa ada beberapa faktor yang mempengaruhi pemahaman konsep matematika peserta didik. Dalam tulisan ini, pembahasan akan difokuskan pada faktorfaktor yang berada dalam ruang lingkup unsur afektif seperti: motivasi belajar, kemandirian belajar, dan kepercayaan diri (Self-confidence). 


\section{Pengaruh Motivasi Belajar Siswa terhadap Pemahaman Konsep Matematika Siswa}

Motivasi belajar merupakan komponen yang penting dalam proses pembelajaran, khususnya dalam ranah pemahaman konsep matematis siswa. Beberapa penelitian yang telah dilakukan sebelumnya menunjukkan adanya pengaruh signifikan dari motivasi belajar terhadap pemahaman konsep matematis siswa. Selain itu, terdapat keterkaitan juga antara motivasi belajar dengan pemahaman konsep matematis siswa.

Penelitian pertama dilakukan oleh Samsudin, Ningsih, dan Trisnawati (2021) yang berjudul "Pengaruh Model Pembelajaran dan Motivasi Belajar Terhadap Kemampuan Pemahaman Konsep Matematika (Eksperimen pada Siswa SMP Swasta di Kabupaten Lebak).” Metode yang digunakan dalam penelitian ini adalah eksperimen dengan model analisis teatment by level. Terdapat 4 kelompok yang dijadikan subjek penelitian, yaitu (1) 16 siswa pada kelompok motivasi tinggi dengan treatment model pembelajaran discovery learning, (2) 16 siswa pada kelompok motivasi rendah dengan treatment model pembelajaran discovery learning, (3) 16 siswa pada kelompok motivasi tinggi dengan pembelajaran konvensionall, dan (4) 16 siswa pada kelompok motivasi rendah dengan pembelajaran konvensional. Hasil penelitian menunjukkan bahwa terdapat perbedaan kemampuan pemahaman konsep matematika dalam pembelajaran jika ditinjau dari motivasi belajar. Kemampuan pemahaman konsep matematika dari kelompok siswa yang memiliki motivasi tinggi dari 32 responden (dengan model pembelajaran discovery learning dan pembelajaran konvensional) diperoleh rata-rata 79,78 sedangkan dari kelompok siswa yang memiliki motivasi rendah dari 32 responden (dengan model pembelajaran discovery learning dan pembelajaran konvensional) diperoleh rata-rata 68,44 . Hal ini menunjukkan bahwa kemampuan pemahaman konsep matematika pada siswa yang memiliki motivasi tinggi lebih tinggi dibandingkan dengan siswa yang memiliki motivasi rendah. Jadi, motivasi belajar berpengaruh positif terhadap kemampuan pemahaman konsep matematika siswa.

Selanjutnya penelitian oleh Tona, Kesumawati, dan Marhamah (2019) yang berjudul "Kemampuan Pemahaman Konsep Matematis Berdasarkan Motivasi Belajar Siswa Melalui Model Pembelajaran LAPS-Heuristic." Logan Avenue Problem SolvingHeuristic (LAPS-Heuristic) merupakan model pembelajaran yang dapat membimbing siswa dalam memahami dan memecahkan permasalahan dengan menggunakan pertanyaan seperti apa permasalahannya, adakah alternatif pemecahannya, bagaimana solusi dan bagaimana sebaiknya mengerjakannya (Purba \& Sirait, 2017). Metode penelitian yang digunakan adalah penelitian kuasi eksperimen (quasi experiment) dengan desain faktorial (factorial design) pada siswa kelas VII.6dan VII. 7 SMP Negeri 15 Palembang. Diperoleh bahwa kelompok siswa dengan motivasi belajar tinggi yang mendapat perlakuan model pembelajaran LAPS-Heuristic memiliki rata-rata 73,27 lebih tinggi dibandingkan dengan kelompok siswa yang mendapat perlakuan konvensional dengan rata-rata 73,125. Kelompok siswa dengan 
motivasi belajar sedang yang mendapat perlakuan model pembelajaran LAPS-Heuristic memiliki ratarata 71,28 lebih tinggi dibandingkan dengan kelompok siswa yang mendapat perlakuan konvensional dengan rata-rata 56,74. Kelompok siswa dengan motivasi belajar rendah yang mendapat perlakuan model pembelajaran LAPS-Heuristic dengan memilki rata-rata 81 lebih tinggi dibandingkan dengan kelompok siswa yang mendapat perlakuan konvensional dengan rata-rata 49. Dapat disimpulkan bahwa motivasi belajar berpengaruh poitif terhadap kemampuan pemahaman konsep matematika siswa.

Kemudian penelitian oleh Risqilah (2015) yang berjudul "Pengaruh Kemandirian Belajar dan Motivasi Belajar Melalui Model Examples Non Examples Terhadap Kemampuan Pemahaman Konsep Materi Kubus dan Balij di MTs Gondang Wonopringgo.” Penelitian ini merupakan penelitian eksperimen. Penelitian ini memakai dua kelas yaitu kelas ekperimen yang menggunakan model examples non examples dan kelas kontrol sebagai kelas uji coba. Diperoleh terdapat pengaruh positif dan signifikan antara kemandirian belajar dan motivasi belajar melalui model Examples Non Examples terhadap kemampuan pemahaman konsep materi kubus dan balok di MTs. Gondang Wonopringgo dengan konstribusi sebesar 73\%. Oleh karena itu, motivasi belajar memiliki pengaruh positif terhadap kemampuan pemahaman konsep matematika siswa.

\section{Pengaruh Kemandirian Belajar terhadap Pemahaman Konsep Matematika Siswa}

Kemandirian belajar adalah salah satu hal penting yang harus dimiliki siswa untuk dapat meningkatkan pemahaman konsep matematika. Hal ini disebabkan karena kemandirian belajar memiliki pengaruh positif terhadap kemampuan pemahaman konsep. Adapun beberapa penelitian yang membahas mengenai pengaruh kemandirian belajar terhadapa kemampuan pemaham konsep matematika siswa.

Penelitian pertama oleh Winata, Friantini, dan Sukirno (2021) yang berjudul "E-Learning: Kemandirian Belajar terhadap Pemahaman Konsep Matematika pada Pembelajaran dengan Google Classroom." Jenis penelitian adalah kuantitatif menggunakan pendekatan ex post facto. Subjek penelitiannya yaitu 130 siswa kelas XI di SMK Negeri 4 Balikpapan. Berdasarkan hasil analisis, diperoleh $R$ Square 34,1\% yang menunjukkan bahwa pemahaman konsep matematika siswa dapat dijelaskan oleh kemandirian belajar sebesar 34,1\% sisanya 65,9\% dijelaskan oleh faktor lain yang tidak diteliti dalam penelitian ini. Jadi, kemandirian belajar memiliki pengaruh terhadap kemampuan pemahaman konsep matematika siswa.

Selanjutnya penelitian oleh Setiawan dan Anawati (2021) yang berjudul "Pengaruh Konsep Diri dan Kemandirian Belajar terhadap Pemahaman Konsep Matematika." Penelitian ini adalah penelitian kuantitatif dengan metode yang digunakan adalah metode survey korelasional. Subjek penelitian yaitu 30 siswa kelas VII SMP Cita Mulia. Hasil pengujian hipotesis penelitian didapatkan $t_{\text {hitung }}=4,705>$ 
$\mathrm{t}_{\text {tabel }}=2,052$, hal ini menunjukkan bahwa ada pengaruh yang signifikan kemandirian belajar terhadap pemahaman konsep matematika. Dapat disimpulkan bahwa kemandirian belajar siswa berpengaruh terhadap kemampuan pemahaman konsep matematika siswa.

Penelitian oleh Yuliana, Surahmat, dan Fathani (2021) yang berjudul "Analisis Kemampuan Pemahaman Konsep Matematis Berdasarkan Kemandirian Belajar pada Materi Sistem Persamaan Linier Dua Variabel (SPLDV) Peserta Didik Kelas VIII MTs Ash-Sholihuddin Dampit." Pendekatan yang digunakan dalam penelitian ini adalah pendekatan kualitatif dengan jenis penelitian deskriptif kualitatif. Subjek penelitian adalah 20 siswa kelas VIII di MTs Ash-Sholihuddin Dampit, kemudian diambil 3 siswa untuk diwawancara yang terdiri dari 1 siswa dengan kemandirian belajar tinggi, 1 siswa dengan kemandirian belajar sedang, dan 1 siswa dengan kemandirian belajar rendah. Dari hasil tes dan wawancara diperoleh siswa dengan kemandirian belajar tinggi memiliki kemampuan pemahaman konsep matematis yang sangat baik, siswa dengan kemandirian belajar sedang memiliki kemampuan pemahaman konsep matematis yang baik, dan siswa dengan kemandirian belajar rendah memiliki kemampuan pemahaman konsep matematis yang kurang baik. Jadi, tingkat kemandirian belajar dapat mempengaruhi kemampuan pemahaman konsep matematika siswa.

\section{Pengaruh Kepercayaan Diri (Self-confidence) terhadap Pemahaman Konsep Matematika Siswa}

Kepercayaan diri (Self-confidence) merupakan komponen yang penting dalam menunjang pemahaman konsep matematis siswa. Seperti yang ditunjukkan pada penelitian yang dilakukan oleh Islami dan Rusliah (2019) dalam penelitian mereka yang berjudul "Pengaruh Self-confidence Terhadap Pemahaman Konsep Matematis Siswa Sekolah Menengah Pertama." Dalam penelitian tersebut, responden berasa dari siswa kelas VIII SMP Negeri 18 Kerinci sebanyak 59 orang dengan teknik pengambilan data total sampling. Instrumen dari penelitian ini terdiri dari angket selfconfidence dan tes pemahaman konsep matematis. Angket terdiri dari 34 item pertanyaan dan tes pemaham konsep matematis terdiri dari 5 item soal. Adapun hasil penelitian tersebut menunjukkan bahwa terdapat pengaruh self-confidence terhadap pemahaman konsep matematis siswa.

Selanjutnya penelitian oleh Nurhandita, Marniati, dan Farman (2021) yang berjudul "Analisis Kepercayaan Diri Siswa dalam Pemahaman Konsep Matematis Siswa Sekolah Menengah Pertama.” Jenis penelitian ini adalah penelitian deskriptif kualitatif. Subjek penelitian adalah 29 siswa kelas IXc di SMPN 2 Latambaga yang dikelompokkan menjadi siswa dengan tingkat kepercayaan diri tinggi, sedang, dan rendah. Indikator pemahaman konsep yang digunakan yaitu (1) Menyatakan Ulang Sebuah Konsep, (2) Mengklasifikasikan Objek-Objek Menurut Sifat-Sifat Tertentu, (3) Menyajikan Konsep Dalam Berbagai Bentuk Representasi Matematis, dan (4) Mengaplikasikan Konsep atau Algoritma dalam Pemecahan Masalah. Hasil penelitian menunjukkan bahwa siswa dengan tingkat kepercayaan diri tinggi mampu menyelesaikan tiga indikator dalam kemampuan pemahaman konsep yaitu indikator 1, 3 dan 4. Siswa dengan tingkat kepercayaan diri sedang mampu menyelesaikan dua 
indikator dalam kemampuan pemahaman konsep yaitu indikator 2 dan 3. Siswa dengan tingkat kepercayaan diri rendah mampu menyelesaikan dua indikator dalam kemampuan pemahaman konsep yaitu indikator 1 dan 4 . Jadi, tingkat kepercayaan diri dapat mempengaruhi pemahaman konsep matematika siswa.

Penelitian oleh Dini, Wijaya, dan Sugandi (2018) yang berjudul "Pengaruh Self-Confidence Terhadap Kemampuan Pemahaman Matemtika Siswa SMP.” Metode dalam penelitian ini menggunakan metode korelasional dengan pendekatan kuantitatif. Subjek penelitian yaitu 28 siswa SMP di Kota Cimahi. Hasil penelitian menunjukkan bahwa kemampuan pemahaman matematik siswa SMP dipengaruhi positif oleh self-confidence sebesar 74,6\% dan 25,4\% dipengaruhi oleh faktor selain self-confidence. Dapat disimpulkan bahwa self-confidence berpengaruh terhadap kemampuan pemahaman konsep matematika siswa. Siswa yang memiliki self-confidence cenderung lebih berani dan kreatif dalam mengambil langkah penyelesaian soal dan cenderung memiliki ide lebih banyak dalam menyelesaikan soal.

\section{KESIMPULAN}

Dari hasil beberapa penelitian yang telah dibahas, terdapat beberapa aspek afektif yang mempengaruhi pemahaman konsep matematika siswa pada sekolah menengah. Aspek afektif tersebut diantaranya yaitu motivasi, kemandirian belajar, dan kepercayaan diri siswa. Dapat disimpulkan bahwa motivasi belajar, kemandirian belajar, dan kepercayaan diri (self-confidence) berpengaruh secara parsial terhadap pemahaman konsep matematika siswa sekolah menengah.

\section{DAFTAR PUSTAKA}

Belanisa, S. (2020). Pengaruh Kemandirian Belajar dan Berfikir Kritis terhadap Pemahaman Konsep Matematika (Survei Pada Mts Swasta di Kota Tangerang Selatan). ALFARISI: Jurnal Pendidikan MIPA, 2(1).

Dini, M., Wijaya, T. T., \& Sugandi, A. I. (2018). Pengaruh Self Confidence Terhadap Kemampuan Pemahaman Matematik Siswa Smp. JURNAL SILOGISME: Kajian Ilmu Matematika dan Pembelajarannya, 3(1), 1-7.

Ferryansyah, F., \& Anwar, A. (2020). Hubungan Kemampuan Awal Matematika dengan Kemampuan Pemahaman Konsep Matematika Siswa Kelas VIII SMP 12 Tarakan. Mathematic Education and Aplication Journal (META), 2(1), 8-14.

Lu'Luilmaknun, U., \& Wutsqa, D. U. (2019, October). Does the use of e-learning media with guided discovery method affect students' understanding of mathematics concept?. In Journal of Physics: Conference Series (Vol. 1320, No. 1, p. 012087). IOP Publishing.

Nurhandita, N., Marniati, M., \& Farman, F. (2021). Analisis Kepercayaan Diri Siswa dalam Pemahaman Konsep Matematis Siswa Sekolah Menengah Pertama. Faktor: Jurnal Ilmiah Kependidikan, 8(2), 202-212. 
Pradipta, D. A. (2018). Pengaruh Minat Belajar dan Komunikasi Matematis Terhadap Pemahaman Konsep Matematika. EKUIVALEN-Pendidikan Matematika, 31(1).

Purba, O. N., \& Sirait, S. (2017). Peningkatan Kemampuan Pemecahan Masalah dengan Model LAPS-Heuristic di SMA Shafiyyatul Amaliyah. Jurnal Mathematic Paedagogic, 2(1), 31-39.

Riana, R., Kartinawati, T., \& Suhito, S. (2019, February). Meningkatkan Kemampuan Pemahaman Konsep dan Motivasi Belajar Siswa SMP Negeri 11 Semarang Melalui Model Group Investigation Berbantuan Colour Ball. In PRISMA, Prosiding Seminar Nasional Matematika (Vol. 2, pp. 64-71).

Risqilah, R. (2017). Pengaruh Kemandirian Belajar dan Motivasi Belajar Melalui Model Examples Non Examples Terhadap Kemampuan Pemahaman Konsep Materi Kubus dan Balij di MTs Gondang Wonopringgo. Delta: Jurnal Ilmiah Pendidikan Matematika, 3(2), 58-64.

Royong, J. A. Y. L. G. (2019). Kemampuan Pemahaman Konsep Matematis Berdasarkan Motivasi Belajar Siswa Melalui Model Pembelajaran LAPS-Heuristic. UNION: Jurnal Pendidikan Matematika, 7 (3), 417-425.

Rusliah, N. R., \& Islami, A. (2020, February). Pengaruh Self Confidence Terhadap Pemahaman Konsep Matematis Siswa Sekolah Menengah Pertama. In Prosiding SI MaNIs (Seminar Nasional Integrasi Matematika dan Nilai-Nilai Islami) (Vol. 3, No. 1, pp. 187-193).

Samsudin, A., Ningsih, E. F., \& Trisnawati, T. (2021). Pengaruh Model Pembelajaran dan Motivasi Belajar Terhadap Kemampuan Pemahaman Konsep Matematika (Eksperimen pada Siswa SMP Swasta di Kabupaten Lebak). Abacus, 2(01), 17-29.

Schunk, D. H. (2012). Teori-teori Pembelajaran: Perspektif Pendidikan. Yogyakarta: Pustaka Pelajar.

Setiawan, W. A., \& Anawati, S. (2021). Pengaruh Konsep Diri dan Kemandirian Belajar terhadap Pemahaman Konsep Matematika. Diskusi Panel Nasional Pendidikan Matematika, 7(1), 381390.

Winata, R., Friantini, R. N., \& Sukirno, S. (2021). E-Learning: Kemandirian Belajar Terhadap Pemahaman Konsep Matematika Pada Pembelajaran dengan Google Classroom. Faktor: Jurnal Ilmiah Kependidikan, 8(2), 148-157.

Yuliana, Y., Surahmat, S., \& Fathani, A. H. (2021). Analisis Kemampuan Pemahaman Konsep Matematis Berdasarkan Kemandirian Belajar pada Materi Sistem Persamaan Linier Dua Variabel (SPLDV) Peserta Didik Kelas VIII MTs Ash-Sholihuddin Dampit. Jurnal Penelitian, Pendidikan, dan Pembelajaran, 16(12), 64-73. 